\title{
Lead accumulation in teeth as a function of age with different exposures
}

\author{
ANNE STEENHOUT ${ }^{1}$ AND M POURTOIS ${ }^{2}$ \\ From Laboratoire Traitement des Eaux et Pollution, ${ }^{1}$ and Laboratoire de Stomatologie, ${ }^{2}$ Université Libre \\ de Bruxelles, Brussels, Belgium
}

ABSTRACT The level of lead exposure in industrial, urban, and rural populations has been evaluated by sampling permanent teeth gathered from three regions of Belgium. When tooth lead concentrations are plotted against tooth age, a linear function appears to fit the empirical results satisfactorily. On the contrary, comparing only the arithmetical means of the three samples would bring a possible bias of the results because their mean ages are different. The slope of the three best regression lines obtained respectively with data from the three regions increases significantly in the sequence rural < urban < industrial. A simplified mathematical model shows that this slope is directly related to the mean intake of lead under uniform exposure. It is suggested that this slope could be used as an index of the population's exposure to lead.

The blood lead (Pb-B) or the free erythrocyte protoporphyrin (FEP) concentrations, or both, are the most commonly used indicators of lead exposure in population surveys. They have both been used to define a "no-effect" lead concentration for children's exposure or a threshold for undue lead absorption. This threshold value has been repeatedly adjusted downwards during the past 20 years as new data have become available on the epidemiology of subclinical effects of low chronic lead exposure.

The blood lead concentration is an "instantaneous" indicator that reflects immediate exposure by giving a static picture of a dynamic process that includes intake, excretion, and tissue storage. Changing the conditions of exposure (or intake) leads to a $\mathrm{Pb}-\mathrm{B}$ variation within about 28 days, ${ }^{1}$ and it is not, therefore, a reliable index of long-term exposure. ${ }^{2} 3$ The rate at which the free erythrocyte protoporphyrin concentration in blood changes after cessation of exposure is not known.

The concentration of lead in teeth, on the contrary, is a cumulative function of earlier exposure. This retrospective look allows the identification of undetected cases of undue lead absorption whenever other indices have returned to normal. In addition, the storage of lead in the teeth of primates has been shown to be dose-dependent. ${ }^{4}$ Low but continuous lead exposure will thus be shown by the tooth lead

Received 25 January 1980

Accepted 9 June 1980 concentration. The relationship between duration of exposure and lead accumulation in teeth offers a possible way of discriminating between populations with different lead exposures.

\section{Material and methods}

SAMPLING

Since May 1978131 permanent teeth, decayed and non-decayed, have been sampled at random from children and adults of both sexes undergoing treatment in private practices or dental schools in Brussels, Hoboken, and Arlon. Clinical data and inquiry cards indicated possible treatments undergone before extraction. Teeth filled with materials suspected to contain lead were discarded. Other information (age, sex, job, home, working or school address, time spent in each place) was noted in order to assess so far as possible sources of lead exposure and their respective contribution to the total exposure of each subject.

\section{ANALYSIS}

The teeth were ashed for 12 hours at $450^{\circ} \mathrm{C}$, then crushed. The powders were ashed for a further four hours at the same temperature, then moistened for one hour. Finally, after drying at $105^{\circ} \mathrm{C}$ for one hour, the powders were weighed and dissolved in $3 \mathrm{ml}$ concentrated nitric acid. Filtered solutions were analysed for lead at $217 \mathrm{~nm}$ by atomic absorption spectrophotometry (on an IL apparatus) with 
an air-acetylene flame and deuterium lamp correction. Blank and standard solutions were treated in the same way. The results of the analyses are expressed in ppm ash weight of the whole tooth.

To evaluate the accuracy of the method five teeth were crushed together. The powder was divided into four different parts. Two were analysed with the method described above and two after digestion by a mixture of concentrated hydrochloric and nitric acids and hydrogen peroxide in the ratio $3: 1: 3$. The results were found to be satisfactorily concordant (less than 10\% discrepancy), showing that the treatment at $450^{\circ} \mathrm{C}$ did not entail any loss of lead.

Some symmetrical teeth from the same donors were analysed. From 10 such pairs the average variability (mean relative SD) has been estimated to be $6.2 \%$. This value includes both the reproducibility of the method and the individual variation.

\section{DETERMINATION OF TOOTH AGE}

Tooth age is used here as the independent variable instead of the age of the donor.

We assume that at the onset of calcification lead that could be stored in the small tooth buds will be in too small a volume to be compared with the whole volume of the mature tooth. Thus these earliest stages have been disregarded and we have set a tooth age of zero at a point when the tooth has achieved a sufficient enamel and dentine volume. This theoretical point, which we have called the "mid-growth stage," has been

Table 1 "Mid-growth stage" determination for each tooth type (calculated from Watson and Lowrey and Graber $^{6}$ )

\begin{tabular}{|c|c|c|c|c|}
\hline Tooth & $\begin{array}{l}\text { Age at onset } \\
\text { of calcifica- } \\
\text { tion } \\
(y r)\end{array}$ & $\begin{array}{l}\text { Age at comple- } \\
\text { tion of root } \\
\text { growth } \\
(y r)\end{array}$ & $\begin{array}{l}\text { Age at mid- } \\
\text { growth } \\
\text { stage } \\
(y r)\end{array}$ & $\begin{array}{l}\text { Total duration } \\
\text { of growth } \\
(y r)\end{array}$ \\
\hline $\begin{array}{l}{[1} \\
1]\end{array}$ & $\begin{array}{l}0.25 \\
0.25\end{array}$ & $\begin{array}{r}7 \pm 0.75 \\
11 \pm 0.75\end{array}$ & $\begin{array}{l}3.625 \\
5.625\end{array}$ & $\begin{array}{r}6.75 \pm 0.75 \\
10.75 \pm 0.75\end{array}$ \\
\hline $\begin{array}{l}2 \\
2 \\
\end{array}$ & $\begin{array}{l}0.58 \\
0.92\end{array}$ & $\begin{array}{r}8 \pm 0.75 \\
11 \pm 0.75\end{array}$ & $\begin{array}{l}4 \cdot 29 \\
5 \cdot 96\end{array}$ & $\begin{array}{r}7.42 \pm 0.75 \\
10.08 \pm 0.75\end{array}$ \\
\hline $\begin{array}{r}3 \\
3 \\
\end{array}$ & $\begin{array}{l}0.50 \\
0.33\end{array}$ & $\begin{array}{l}12 \pm 0.5 \\
15 \pm 0.5\end{array}$ & $\begin{array}{l}6 \cdot 25 \\
7 \cdot 67\end{array}$ & $\begin{array}{l}11.5 \pm 0.5 \\
14.67 \pm 0.5\end{array}$ \\
\hline $\begin{array}{r}4 \\
4] \\
\end{array}$ & $\begin{array}{l}1 \cdot 75 \\
2.0\end{array}$ & $\begin{array}{l}12 \pm 0.5 \\
15 \pm 0.5\end{array}$ & $\begin{array}{l}6 \cdot 875 \\
8 \cdot 5\end{array}$ & $\begin{array}{l}10.25 \pm 0.5 \\
13.0 \pm 0.5\end{array}$ \\
\hline $\begin{array}{l}5 \\
5 \\
\end{array}$ & $\begin{array}{l}2 \cdot 25 \\
2 \cdot 25\end{array}$ & $\begin{array}{l}12 \pm 0.5 \\
15 \pm 0.5\end{array}$ & $\begin{array}{l}7 \cdot 125 \\
8 \cdot 625\end{array}$ & $\begin{array}{r}9.75 \pm 0.5 \\
12.75 \pm 0.5\end{array}$ \\
\hline $\begin{array}{l}6 \\
6 \\
\end{array}$ & $\begin{array}{l}-0.08 \\
-0.08\end{array}$ & $\begin{array}{r}8 \pm 0.75 \\
10 \pm 0.75\end{array}$ & $\begin{array}{l}3.96 \\
4.96\end{array}$ & $\begin{array}{r}8.08 \pm 0.75 \\
10.08 \pm 0.75\end{array}$ \\
\hline $\begin{array}{l}77 \\
7] \\
\end{array}$ & $\begin{array}{l}3 \cdot 0 \\
2 \cdot 5\end{array}$ & $\begin{array}{l}15 \pm 0.5 \\
15 \pm 0.5\end{array}$ & $\begin{array}{l}9 \cdot 0 \\
8 \cdot 75\end{array}$ & $\begin{array}{l}12.0 \pm 0.5 \\
12.5 \pm 0.5\end{array}$ \\
\hline $\begin{array}{l}\sqrt{8} \\
8 \\
\end{array}$ & $\begin{array}{l}9.0 \pm 0.75 \\
9.0 \pm 0.75\end{array}$ & $\begin{array}{l}21 \cdot 0 \\
21 \cdot 0\end{array}$ & $\begin{array}{l}15.0 \\
15.0\end{array}$ & $\begin{array}{l}12.0 \pm 0.75 \\
12.0 \pm 0.75\end{array}$ \\
\hline
\end{tabular}

calculated for each type of tooth from the data given by Watson and Lowrey ${ }^{5}$ or Graber ${ }^{3 *}$ (table 1). The age at the mid-growth stage for each type of tooth is obtained by considering the mid-mean difference between the age of the completion of root growth and the age at the onset of calcification.

The age of each tooth is determined as the time between its specific mid-growth stage and the donor's age at the time of avulsion. It will represent here the duration of significative tooth exposure, the level of which is being regarded here as uniform.

\section{Results}

Teeth were collected from: (1) an industrial region with lead pollution from a non-ferrous metal smelter plant (Hoboken, Province of Antwerp); (2) an urban region where lead exposure comes mainly from traffic and from lead pipes used to supply water (Brussels); and (3) a rural region that is assumed to be less exposed to lead (Arlon, south of the Province of Luxembourg).

\section{TOOTH LEAD CONCENTRATION}

For each region, the means and the $90 \%$ confidence interval of the lead content of all the teeth analysed are given in table 2 . The lead content of the teeth from Hoboken is significantly different from the means in the other regions (at the $95 \%$ confidence level). Mean lead concentrations in the teeth from Brussels and Arlon do not differ significantly from each other (at the $90 \%$ level of confidence). This is probably due to the method of collection of the samples, which happened to provide older teeth from Arlon than from Brussels (table 2).

Table 2 Mean content of lead in permanent teeth from male and female subjects (including children)

\begin{tabular}{llll}
\hline Region & $\begin{array}{l}\text { Mean lead con- } \\
\text { centration }(p p m \\
\pm 90 \% \text { confidence }\end{array}$ & $\begin{array}{l}\text { Range } \\
(p p m)\end{array}$ & $\begin{array}{l}\text { Mean tooth age } \\
(y r)\end{array}$ \\
\hline interval) & \\
\hline $\begin{array}{l}\text { Hoboken } \\
(\mathrm{n}=51)\end{array}$ & $35 \cdot 35 \pm 6.00$ & $5 \cdot 4-110.7$ & 33.55 \\
$\begin{array}{l}\text { Brussels } \\
(\mathrm{n}=42)\end{array}$ & $17 \cdot 72 \pm 4 \cdot 16$ & $2 \cdot 3-68.0$ & 18.91 \\
$\begin{array}{l}\text { Arlon } \\
(\mathrm{n}=38)\end{array}$ & $21.45 \pm 4 \cdot 35$ & $1.2-69.3$ & 35.91 \\
\hline
\end{tabular}

* Since submitting the manuscript we have seen the study of HC Slavkin: Developmental craniofacial biology. Philadelphia: Lea and Febiger, 1979. His range of data appears to be the same as in table 1 . 

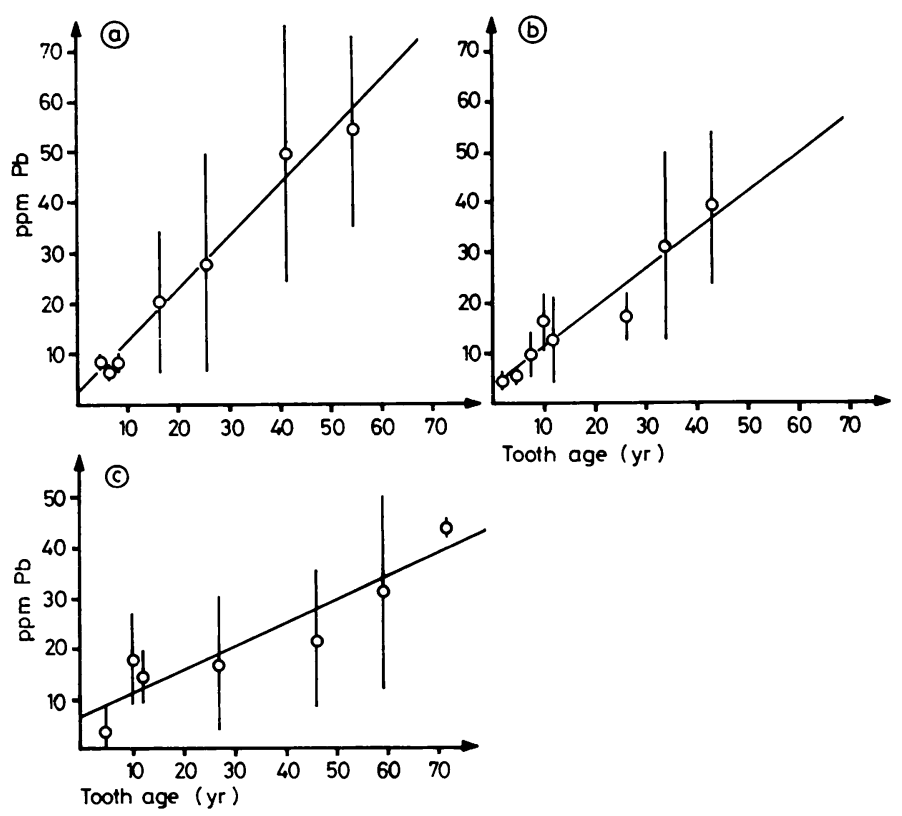

Fig 1 Lead content in permanent teeth as a function of tooth age in the three regions studied: mean lead content for each age group is given with its standard deviation (men and women together). (a) Industrial region (Hoboken): $n=51$ teeth within seven age groups; (b) urban region (Brussels): $n=42$ teeth within eight age groups; (c) rural region (Province of Luxembourg): $n=38$ teeth within seven age groups.

\section{LEAD CONTENT IN TEETH AS A FUNCTION OF AGE}

Figure $1(a, b, c)$ shows the mean lead content of teeth (and the standard deviation) by age. The lead concentration at presumed constant exposurethat is, in teeth from the same geographic regionincreased regularly with age and a linear function fits the observed increase satisfactorily.

Table 3 Lead exposure indices in three environments for children and adults of both sexes

\begin{tabular}{llllll}
\hline Region & $\begin{array}{l}\text { No of } \\
\text { samples }\end{array}$ & $\begin{array}{l}a=\text { Slope } 90 \% \text { Con- } b=y \\
\text { of linear } \\
\text { regression }\end{array}$ & $\begin{array}{l}90 \% \text { Con- } \\
\text { fimits }\end{array}$ & Intercept & $\begin{array}{l}\text { fidence } \\
\text { limits }\end{array}$ \\
\hline $\begin{array}{l}\text { Rural } \\
(\mathbf{r}=0.93)\end{array}$ & 38 & 0.45 & \pm 0.17 & 6.61 & \pm 6.86 \\
$\begin{array}{l}\text { Urban } \\
(\mathbf{r}=0.96)\end{array}$ & 42 & 0.78 & \pm 0.17 & 3.70 & \pm 3.83 \\
$\begin{array}{l}\text { Industrial } \\
(\mathrm{r}=0.99)\end{array}$ & 51 & 1.03 & \pm 0.14 & 2.07 & \pm 4.03 \\
\hline
\end{tabular}

\section{COMPARISON OF THE THREE LEVELS} OF EXPOSURE

The parameters of the regression lines in fig 1 are grouped in table 3 . The $90 \%$ confidence limits for $(a)$ each slope and $(b)$ each $y$ intercept have been estimated and the slopes of the regression lines allow exposure in each region to be compared.

The slope for Brussels is significantly higher than that for the rural zone and the slope for the industrial region is significantly higher than that for the rural zone; it is also significantly higher than that for the urban. The three levels of exposure-industrial, urban, and rural-therefore, significantly differ from each other (at the $90 \%$ confidence level).

At this point of the study, as indicated by the overlapping confidence intervals (table 3 ), we cannot interpret the values calculated for $(b)$ in the three regions, which would represent the mean lead content at the mid-growth stage for all types of tooth. It is unlikely that it would be greatest in the rural and least in the industrial area. The differences in the composition in the different tooth types between 
Table 4 Lead exposure indices for men against women in the industrial region

\begin{tabular}{llllll}
\hline Sex & No & $\begin{array}{l}a=\text { Slope } \\
\text { of linear } \\
\text { regression }\end{array}$ & $\begin{array}{l}90 \% \text { Con- } \begin{array}{l}b=y \\
\text { limits }\end{array} \\
\text { Intercept }\end{array}$ & $\begin{array}{l}90 \% \text { Con- } \\
\text { fidence } \\
\text { limits }\end{array}$ \\
\hline $\begin{array}{l}\text { Women } \\
(\mathrm{r}=0.999)\end{array}$ & 17 & 0.65 & \pm 0.03 & 2.79 & \pm 0.96 \\
$\begin{array}{l}\text { Men } \\
(\mathrm{r}=0.995)\end{array}$ & 34 & 1.01 & \pm 0.14 & 5.61 & \pm 4.72 \\
\hline
\end{tabular}

the three samples could be partly reflected here. A type-by-type study of lead content in teeth against tooth age would probably remove this uncertainty, but the number of teeth presently available is insufficient to allow for such a detailed statistical analysis.

DIFFERENCE IN EXPOSURE RELATED TO SEX In the sample from Brussels and Arlon no significant difference (at the $90 \%$ confidence level) was found between the exposure of men and women as characterised by the slope of the regression line of tooth lead concentration against tooth age.

In Hoboken, however, the slope is significantly greater for men than for women (table 4, fig $2(a, b)$ ). This may result partly from occupational exposure since, although no workers from the lead factory itself were included in the study, about one-fifth of the men were thought likely to be exposed to a certain extent in the shipyard, and male subjects live closer to the plant than women. More detailed information about exposure to lead would probably explain this observation.

\section{Discussion}

Lead content was measured in the permanent teeth of three different populations of children and adults. The mean value of the industrial sample is significantly higher than those of the two other areas (at the $95 \%$ confidence level), but mean values in the urban and in the rural regions are not significantly different (at the 90\% confidence level). The sample in the rural region, however, contained teeth from older people than in Brussels (table 2) and this may distort the results somewhat; indeed, comparing the arithmetical means of the samples from different regions would be unsuitable.

Tooth age has been shown to be a useful concept and is likely partly to explain the differences in lead concentrations between the different tooth types observed by other investigators. ${ }^{7-11}$ Using this independent variable, we can consider together all the different tooth types sampled in each region and plot the results against the time that has elapsed since the mid-growth stage. Figure $1(\mathrm{a}, \mathrm{b}, \mathrm{c})$ shows that lead content in teeth, classified into age groups, tends to increase linearly with age.

Ninety per cent of lead absorbed is stored in the skeletal tissues, from which the turnover time is about 78 years (Garrels ${ }^{12}$ from Rabinowitz ${ }^{1}$ ). From some studies of lead accumulation in bone with age, it appears that the lead content may level off at the age of $50 .^{13}$ This observation is concordant with a kinetic model in which lead accumulation at constant exposure would be described as resulting from a constant intake and a first-order elimination, according to the equation:

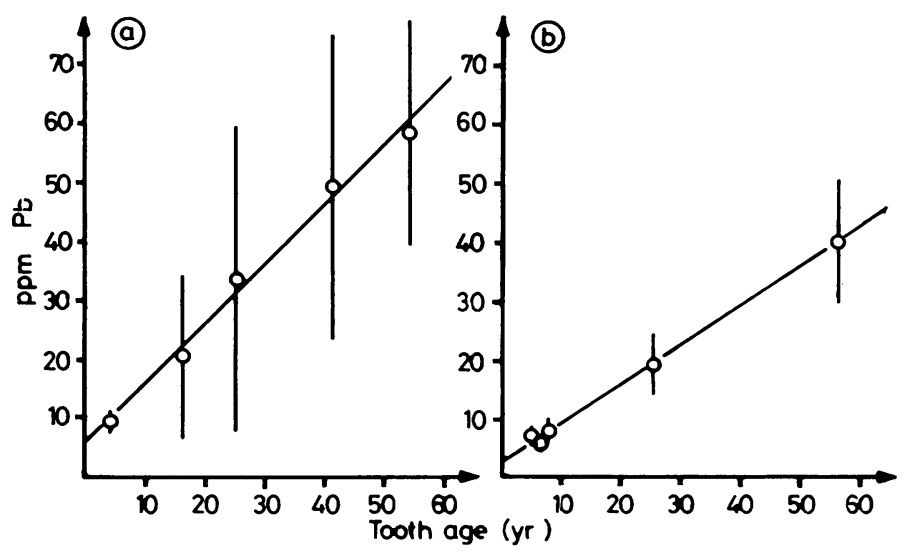

Fig 2 Lead content in permanent teeth as a function of tooth age and sex. Industrial region only. (a) Men: $n=34$ teeth within five age groups; (b) women: $n=17$ teeth within five age groups. 


$$
\frac{d q_{3}}{d t}=k_{1} q_{1}-k_{3} q_{3}
$$

where $q_{1}$ is the blood lead concentration and $q_{3}$ the lead concentration in the skeletal tissue compartment. With the initial condition $q_{3}=\left(q_{3}\right)_{0}$, at time zero, this solution of the equation (1) is

$$
q_{3}=\frac{k_{1} q_{1}}{k_{3}}-C e^{-k_{3} t}
$$

where $C=\frac{k_{1} q_{1}}{k_{3}}-\left(q_{3}\right)_{0}$.

Other authors ${ }^{14-18}$ have used a linear function to describe lead accumulation in bone with age. Altshuller et al, ${ }^{7}$ working with deciduous teeth, described a linear increase in the lead content with age. These results, like ours, can be represented by a model in which lead mobilisation from skeletal tissues is neglected. In any case this assumption is adequate for permanent teeth since, unlike bone, dental tissue once fully formed does not undergo a remodelling process.

The model then becomes:

$$
\frac{d q_{3}}{d t}=k_{1} q_{1}
$$

With the same initial condition as above, the solution is an equation of a linear function:

$$
q_{3}=\left(k_{1} q_{1}\right) t+\left(q_{3}\right) 0
$$

Some authors have plotted the logarithm of the lead concentration in permanent ${ }^{19}$ or deciduous ${ }^{20}$ teeth against the age of the donor, assuming an exponential relationship. This would imply an exponential increasing intake, which seems difficult to substantiate if the exposure is not varying. For deciduous teeth, the problem is not yet solved, since Proud $^{9}$ and Habercam et $a^{21}$ found no evident relationship between age and the lead content of the teeth, whereas Mackie et al ${ }^{10}$ did only for canines; Pinchin et $a l^{11}$ found a significant negative regression of lower deciduous molar mean lead content on age. Holtzman, ${ }^{14}$ by contrast with what he found in bone, did not see any increase in lead concentration of teeth after the second decade. Owing to the small number of his samples, however, this result might not be significant.

According to the simplified model above (2), the slope of lead accumulation in permanent teeth represents the annual lead increase resulting from a constant level of exposure. Thus the slopes of the regression lines (fig $1(\mathrm{a}, \mathrm{b}, \mathrm{c})$ ) allow population exposure in the three considered areas (table 3) to be compared. We suggest that the angular coefficient of the best regression lines is the best index of population exposure to lead. This index is highest in the industrial region. Environmental studies (see Steenhout ${ }^{22}$ for extended bibliography) have indicated that a non-ferrous metal smelter (which lies in Hoboken, near Antwerp) is the main source of lead pollution. The population exposure in this area has been studied by blood lead surveys in children, ${ }^{23}$ including very young children, ${ }^{24}$ and by deciduous tooth lead concentrations. ${ }^{22}$ Predominant south-west winds deposit heavy metal particles $(\mathrm{Pb}, \mathrm{Cd}$. . .) for distances up to $3-4 \mathrm{~km}$ in the inhabited area. From September to December 1973 the daily average concentration of total airborne lead $700 \mathrm{~m}$ from the plant was $5.4 \mu \mathrm{gPb} / \mathrm{m}^{3}$. It was $2.6 \mu \mathrm{gPb} / \mathrm{m}^{3}$ at a distance of 1.5 $\mathrm{km}$ for the same period. ${ }^{25}$ General sources of urban lead pollution have also to be taken into account in this region.

In the urban region there are two main sources of lead exposure.

(1) Air lead concentrations which depend on traffic density. In Brussels in 1976 the airborne concentration was estimated at $0.74 \mu \mathrm{gPb} / \mathrm{m}^{3}$ in a street with a low traffic density, but values of 2-5 $\mu \mathrm{gPb} / \mathrm{m}^{3}$ were found elsewhere in the same city in 1972-3 (monthly mean values for four-hour periods of intensive traffic). ${ }^{26}$

(2) Drinking water-In old buildings water may be contaminated due to leaching of lead from supply pipes.

Lower exposures occur in the rural region, although some sources are probably still present. One of these might be lead-contaminated drinking water. A few analyses of well water or house domestic water in the Arlon district showed lead concentrations sometimes twice as high as the World Health Organisation norm value (50 ppb).

The three types of long-term exposure-industrial, urban, and rural-thus differ from each other ( $90 \%$ confidence level). This can also be inferred for present exposure from a comparison of the various blood lead surveys in Belgium: adult $\mathrm{Pb}-\mathrm{B}$ of people from urban regions (Brussels ${ }^{26}$ or Liège ${ }^{27}$ ) seems to be lower than those for adult inhabitants of the industrial region (with no lead workers ${ }^{28}$ ). Surveys of children show even more important differences. ${ }^{23} 28$

Other authors have also studied lead concentration in teeth and bone as a function of age but did not give much information about the exposure of their subjects. Table 5 shows the values of the slope of $\mathrm{Pb}$ increase in permanent teeth and bones, calculated from the data available in publications for different regions. The range of exposure appears to be the same as we found in Belgium (table 3).

One problem is to know what the background of lead accumulation is in teeth-that is, the level of accumulation in teeth with minimum exposure. 
Table 5 Linear accumulation of lead in bone or permanent teeth as related with age of donor (publications review)

\begin{tabular}{|c|c|c|c|c|c|c|c|c|c|}
\hline \multirow{2}{*}{$\begin{array}{l}\text { Bio-indicator } \\
\text { of exposure }\end{array}$} & & \multirow[t]{2}{*}{ Geographic area } & \multirow[t]{2}{*}{ Exposure } & \multicolumn{5}{|c|}{ Indices of exposure } & \multirow[t]{2}{*}{ References } \\
\hline & & & & $\begin{array}{l}\text { No of } \\
\text { samples* }\end{array}$ & $\begin{array}{l}\text { Slope of } \\
\text { regression } \\
\text { line } \\
(\mu g / g / \text { year })\end{array}$ & $\begin{array}{l}\text { Confidence } \\
\text { limits }\end{array}$ & $y$ Intercept & $\begin{array}{l}\text { Confidence } \\
\text { limits }\end{array}$ & \\
\hline Rib & (b) & Paris area & Unknown & 154 & 0.87 & 一 & 0 (forced) & - & Jeanmaire et $a l^{17}$ \\
\hline Vertebrae & (b) & & & 124 & 1.03 & - & 0 (forced) & - & \\
\hline Normal bone & (b) & Chicago/Illinois & $\begin{array}{l}\text { Urban, non-occu- } \\
\text { pational exposure }\end{array}$ & 73 & 0.605 & \pm 0.089 & 3.63 & $\pm 4 \cdot 13$ & Holtzman et $o l^{14}$ \\
\hline Femur & $\begin{array}{l}(a) \\
(b)\end{array}$ & Japan & & & $\begin{array}{l}0.37 \\
0.61\end{array}$ & & -0.65 & & $\begin{array}{l}\text { Horiuchi et } a^{29} \\
\text { (calculated by } \\
\text { Holtzman) }\end{array}$ \\
\hline $\begin{array}{l}\text { Rib } \\
\text { in } 0-49 \\
\text { year group }\end{array}$ & (b) & USA cities & $\begin{array}{l}\text { Urban, non-occu- } \\
\text { pational exposure }\end{array}$ & 62 & $1 \cdot 03$ & $\pm \mathbf{0} \cdot 10$ & $0($ forced $)$ & & $\begin{array}{l}\text { Schroeder et } a^{13} \\
\text { (calculated by } \\
\text { Holtzman) }\end{array}$ \\
\hline Teeth & & Delaware & $\begin{array}{l}\text { Assumed urban } \\
\text { and rural exposure }\end{array}$ & 336 & 0.74 & $\pm 0 \cdot 17(c)$ & $3 \cdot 53$ & $\pm 7 \cdot 70(c)$ & $\begin{array}{l}\text { Calculated from } \\
\text { Wilkinson } \text { et } a^{30}\end{array}$ \\
\hline Tibia & $\begin{array}{l}(a) \\
(b)\end{array}$ & $\begin{array}{l}\mathrm{N}-\mathrm{E} \text { of } \\
\text { England }\end{array}$ & $\begin{array}{l}\text { Urban, non-occu- } \\
\text { pational exposure } \\
\text { in a strongly in- } \\
\text { dustrial but non- } \\
\text { lead region }\end{array}$ & 124 & $\begin{array}{l}0.47 \\
0.67\end{array}$ & $\pm 0.08(c)$ & $-2 \cdot 89$ & $\pm 4 \cdot 65(c)$ & $\begin{array}{l}\text { Calculated from } \\
\text { Barry }{ }^{18}\end{array}$ \\
\hline
\end{tabular}

(a) $=$ Wet weight basis.

(b) $=$ Ash weight basis.

(c) = Confidence limits calculated at the $90 \%$ level.

$*$ Both sexes.

Some studies have reported very low values for ancient preindustrial civilisations $-0.9 \mathrm{ppm}$ in both secondary circumpulpal dentine and cortical bone from Nubians who lived about 5000 years $\mathbf{a g o}^{31}$ and 0.1 to $0.23 \mathrm{ppm}$ in tooth enamel of four ancient Peruvian people buried 1600 years ago. ${ }^{32}$ Secondary circumpulpal dentine of Lacandon Indians, a living preindustrialised population, contains a mean value of $4.3 \mathrm{ppm} .^{33}$ The study of Wilkinson and Palmer ${ }^{30}$ which looked at the lead content in ancient whole teeth (200 to $600 \mathrm{AD}$ ), did not display any relationship between lead concentration and age, although these authors did not rule out possible contamination from soil water. Their results level up a value of about $3.5 \mathrm{ppm}(\mathrm{n}=26)$ taking all the age groups together.

Steady impregnation of teeth at uniform exposure raises the question: what is the nature of the binding process of lead in both the mineral and organic phases of enamel and dentine? It seems that the gradual maturation of calcified tissues and the relative reduction of the organic phase does not impair their ability to store lead. It is therefore likely that the mineral portion itself largely collects lead. It has been established ${ }^{34} 35$ that circumpulpal dentine is the main site for lead deposition. Uninterrupted incorporation of lead in adult teeth also suggests that the highest values we found are still below tooth storage capacity.

We are grateful to the dentists Mr Maex (Hoboken), Mrs Georges and Mr Everling (region of Arlon), and Miss Rerren (Brussels) for help in collecting the teeth and information on the samples and the donors.

We are indebted to Professor Dr R Wollast for helpful discussion during the course of this work.

\section{References}

${ }^{1}$ Rabinowitz MP, Wetherell GW, Kopple JD. Lead metabolism in the normal human: stable isotope studies. Science 1973;182:725-7.

${ }^{2}$ Needleman HL. Incidence and effects of low level lead exposure. International conference on heavy metals in the environment: Toronto, Ontario, Canada, 27-31 October 1975. Toronto: TC Hutchinson, 1976: 183-92.

${ }^{3}$ Needleman HL, Gunnoe CG, Leviton A, et al. Deficits in psychologic and classroom performance of children with elevated dentine lead levels. N Engl J Med 1979: 300:689-95.

${ }^{4}$ Strehlow CD. The use of deciduous teeth as indicators of lead exposure. New-York: New-York University, 1972. (Doctoral dissertation.)

${ }_{5}^{5}$ Watson $\mathrm{EH}$, Lowrey $\mathrm{GH}$. Growth and development in children. 5th ed. Chicago: Year Book Medical Publishers, Inc, 1967.

- Graber PM. Orthodontics: principles and practice. 3rd ed. Philadelphia: Saunders Co, 1972.

7 Altshuller LF, Halak DB, Landing BH, Kehoe RA. Deciduous teeth as an index of body burden of lead. J Pediatr 1962;60:224-9.

${ }^{8}$ Lockeretz W. Lead content of deciduous teeth of children in different environments. Arch Environ Health 1975; 30:583-7.

9 Proud M. A study of the lead levels in deciduous teeth in Leicester children. $J$ Dent Res 1976;55, abstract, D 109. 
${ }^{10}$ Mackie AC, Stephens R, Townshend A, Waldron HA. Tooth lead levels in Birmingham children. Arch Environ Health 1977;32:178-85.

11 Pinchin MJ, Newhalm J, Thompson RPJ. Lead, copper. and cadmium in teeth of normal and mentally retarded children. Clin Chim Acta 1978;85:89-94.

12 Garrels RM, Mackenzie FT, Hunt C. Lead metabolism in humans-A three reservoir model. Chemical cycles and the global environment: assessing human influences. Los Altos: W Kaufmahn, Inc, 1975:173-7.

${ }^{13}$ Schroeder HA, Tipton IH. The human body burden of lead. Arch Environ Health 1968;17:965-78.

${ }^{14}$ Holtzman RB, Lucas HF Jr, Ilcewitz FH. The concentration of lead in human bone. Argonne National Laboratory Publication 1968:43-9. (No Anl-7615.)

15 Barry PSI, Mossman DB. Lead concentrations in human tissues. Br J Ind Med 1970;27:339-51.

${ }^{16}$ Barry PSI. A comparison of lead concentrations in human bones and in soft tissues. International symposium environmental health aspects of lead: Amsterdam, 2-6 October 1972. Luxembourg: Commission of the European Communities, 1973:415-27.

17 Jeanmaire L, Patti F, Cialella N, Gros R. Mesure du Pb dans les os humains provenant de la région parisienne. International Symposium for the Environment and Health. Paris: Commission of the European Communities, 1974:2225-30.

${ }^{18}$ Barry PSI. A comparison of concentrations of lead in human tissues. Br J Med 1975;32:119-39.

${ }^{19}$ Strehlow CD, Kneip TJ. The distribution of lead and zinc in the human skeleton. Am Ind Hyg Assoc J 1969;30: 372-8.

${ }^{20}$ Stewart DJ. Teeth as indicators of exposure of children to lead. Arch Dis Child 1974:49:895-7.

${ }^{21}$ Habercam JW, Keil JE, Reigart JR, Craft HW. Lead content of human blood, hair and deciduous teeth. Correlation with environmental factors and growth. $J$ Dent Res 1974;53:1160-3.

${ }^{22}$ Steenhout A. Pollution et santé: l'exemple de Hoboken. Bruxelles: GERM, 1979. (Lettre d'information, No 130.)

${ }^{23}$ Roels H, Buchet JP, Lauwerijs R, et al. Lead and cadmium absorption among children near a non-ferrous metal plant. Environ Res 1978;15:290-308

${ }^{24}$ Clara R, Deelstra H, Eylenbosch W, Masschelein R, Merckx K, Coeck R. Rapport van het onderzoeksteam aangesteld om de milieu verontreininging te Hoboken te bestuderen. Hoboken: published by the district administration, 1977.

${ }^{25}$ Roels $\mathrm{H}$, Buchet JP, Lauwerijs $\mathrm{R}$, et al. Impact of air pollution by lead on the heme biosynthetic pathway in school-age children. Arch Environ Health 1976;31:310-6.

${ }^{26}$ Lafontaine A, Aerts J, Bruaux $\mathrm{P}$, et al. Le plomb dans l'environnement en Belgique. Groupe Belge de contact "Environmental lead" (IHE). Archives Belges de Médecine Sociale, Hygiène, Médecine du Travail et Médecine légale. 1977; No 1 et 2.

27 Sartor F, Rondia D. Blood lead levels and age: A study in two male urban populations not occupationally exposed. Arch Environ Health 1980;35:110-6.

28 Verheyden J. Bevolkingsonderzoek inzake lood te Hoboken. $A$ report by the Provinciaal Instituut voor Hygiene (Provincie Antwerpen). Antwerp: PIH, 1978-9.

${ }^{29}$ Horiuchi K, Horiguchi S, Suekane M. Studies on the industrial lead poisoning. I Absorption, transportation, deposition, and excretion of lead. 6 The lead contents in organ-tissues of the normal Japanese. Osaka City Med J 1959;5:41-70.

${ }^{30}$ Wilkinson DR, Palmer W. Lead in teeth as a function of age. International Laboratory 1975; May/June:41-47.

${ }^{31}$ Grandjean P, Nielsen OV, Shapiro IM. Lead retention in ancient Nubian and contemporary populations. Journal of Environmental Pathology and Toxicology $1979 ; 2: 781-7$

${ }^{32}$ Ericson JE, Shirahata H, Patterson CC. Skeletal concentrations of lead in ancient Peruvians. $N$ Engl $J$ Med 1979;300:947-51.

${ }^{33}$ Shapiro IM, Mitchell G, Davidson I, Katz SH. The lead content of teeth. Arch Environ Health 1975;30:483-6.

${ }^{34}$ Carroll KG, Needleman HL, Tuncay OC, Shapiro IM. The distribution of lead in human deciduous teeth. Experientia $1972 ; 28: 434-5$.

${ }^{35}$ Shapiro IM, Needleman HL, Tuncay OC. The lead content of human deciduous and permanent teeth. Environ Res 1972;5:467-70. 